\title{
ANALISIS DAN PERANCANGAN SISTEM PENDUKUNG KEPUTUSAN PEMILIHAN PEMASOK TERBAIK DARI PEMASOK TERSEDIA DENGAN METODE ANALYTICAL HIERARCHY PROCESS (AHP): STUDI KASUS DIVISI POWER PT GUNA ELEKTRO
}

\author{
Daniel Kartawiguna; Yohanes Adityo Prayudo; Maureen Sutiono; Hendry Roesly \\ Information Systems Department, School of Information Systems, Binus University \\ Jl. K.H. Syahdan No. 9, Palmerah, Jakarta Barat 114801 \\ daniel.kartawiguna@gmail.com
}

\begin{abstract}
The purpose of this study is to develop a decision support system to support supplier selection process in PT Guna Elektro and also to develop a system that could provide alternatives to the selection of the best suppliers. The methodologies used in this study are analysis, design, and literature study. Analysis will be done by conducting a survey about the current company system, conducting interviews with system users, and then analyzing the survey results. The literature study is conducted by searching reference sources related to the study while the design is conducted by designing a data management subsystem, model, knowledge base, and user interface. The result on the development of the decision support system application can be used to select the most appropriate supplier which are suitable with the criteria required. The developed decision support system helps support the decision making process for supplier selection.
\end{abstract}

Keywords: system, decision, supplier selection, analytical hierarchy process (AHP)

\begin{abstract}
ABSTRAK
Tujuan penelitian ini adalah membangun sebuah sistem pendukung keputusan untuk mendukung proses pemilihan pemasok pada PT Guna Elektro serta membangun sebuah sistem yang bisa memberikan alternatifalternatif pemilihan pemasok terbaik. Metode penelitian yang digunakan adalah metode analisis, metode perancangan dan studi kepustakaan. Dalam metode analisis yang dilakukan adalah mensurvei sistem perusahaan yang berjalan, melakukan wawancara dengan pengguna sistem, menganalisis hasil survei. Dalam studi kepustakaan yang dilakukan dengan mencari sumber-sumber referensi yang berkaitan dengan penelitian yang dilakukan. Sedangkan dalam metode perancangan yang dilakukan adalah merancang subsistem menajemen data, model, basis pengetahuan, dan antarmuka pengguna. Hasil yang dicapai adalah terciptanya suatu aplikasi sistem pendukung keputusan yang dapat digunakan untuk memilih pemasok mana yang paling tepat dan sesuai dengan kriteria yang dibutuhkan. Sistem ini membantu mendukung proses pengambilan keputusan untuk pemilihan pemasok.
\end{abstract}

Kata kunci: sistem, keputusan, pemilihan pemasok, analytical hierarchy process (AHP) 


\section{PENDAHULUAN}

PT Guna Elektro yang berkantor pusat di Jakarta merupakan perusahan yang bergerak di bidang elektronik, mekanikal dan infrastruktur komunikasi di Indonesia. Perusahaan ini juga mempunyai anak perusahaan yang salah satunya memproduksi alat-alat listrik berdaya besar yang biasa di gunakan oleh PLN atau perusahaan pengeboran minyak. Selain itu perusahaan ini juga banyak menjalin kerjasama dengan perusahaan-perusahaan asing ternama. PT Guna Elektro memfokuskan bisnisnya dari pendapatan proyek-proyek baik dari pemerintahan maupun dari perusahaan swasta. Dalam situasi ini ditemukan adanya masalah yang tidak terstruktur pada manajer tingkat atas karena sulitnya menentukan penilaian pemasok yang dapat memberikan kualitas dan harga terbaik serta tepat waktu dalam pengerjaan dan pengirimannya, agar sesuai dengan standar kriteria perusahaan. Oleh karena itu dipandang perlu untuk dapat membangun sebuah sistem pendukung keputusan untuk mendukung proses pemilihan pemasok terbaik dari daftar pemasok Divisi Power PT Guna Elektro.

Adapun ruang lingkup penelitian ini adalah menganalisis sistem pengadaan barang (procurement) dan seleksi pemasok yang sedang berjalan di Divisi Power PT Guna Elektro. Hasil analisis yang diperoleh akan dilanjutkan pada tahap perancangan dan pengembangan sistem pendukung keputusan yang mampu mendukung proses pemilihan pemasok terbaik dari daftar pemasok yang dimiliki olah Divisi Power PT Guna Elektro. Tujuan yang hendak dicapai dari penelitian ini adalah untuk membangun sebuah sistem pendukung keputusan untuk mendukung proses pemilihan pemasok terbaik dari daftar pemasok yang sudah ada serta dapat memberikan alternatifalternatif pemilihan pemasok terbaik berdasarkan kriteria yang ditetapkan. Adapun manfaat yang diperoleh dalam penelitian ini adalah mengembangkan suatu sistem yang dapat membantu manajer dalam pengambilan keputusan pemilihan pemasok terbaik. Dengan pemilihan pemasok yang tepat, diharapkan pemasok yang terpilih akan sesuai dengan kriteria yang diinginkan oleh Divisi Power PT Guna Elektro.

\section{METODE}

Penelitian ini dimulai dengan melakukan studi kepustakaan dengan mencari sumber-sumber referensi yang berkaitan dengan penelitian yang dilakukan. Sumber-sumber referensi tersebut diperoleh melalui buku, artikel, dan jurnal online dari internet sebagai landasan teori. Berdasarkan teori yang ada, kemudian dilanjutkan dengan tahapan analisis sistem melalui lima tahapan. Tahap pertama dimulai dengan melakukan survei sistem yang sedang berjalan, wawancara dengan manajer yang bersangkutan di perusahaan untuk mendapatkan informasi yang jelas dan akurat, analisis hasil survei: menyaring dan menganalisis kembali informasi yang telah didapatkan sesuai dengan sistem yang akan dibangun. Identifikasi kebutuhan informasi. Hasil analisis dijadikan masukan bagi perancangan SPK. Metode perancangan sistem dilakukan dengan alat bantu perancangan sistem, yaitu: Data Flow Diagram, Entity Relationship Model, dan State Transition Diagram (STD). Metode perancangan sistem ini digunakan untuk perancangan subsistem manajemen data, perancangan subsistem manajemen model, dan perancangan subsistem antarmuka pengguna.

\section{HASIL DAN PEMBAHASAN}

\section{Studi Pustaka}

Sistem Pendukung Keputusan (SPK) 
Sebelum mengambil keputusan pertama-tama kita harus memahami masalah yang ada, kemudian kita juga harus mengerti kebutuhan dan tujuan dari keputusan tersebut. Pengambilan keputusan melibatkan banyak kriteria dan sub kriteria yang digunakan untuk menentukan peringkat alternatif keputusan. Kriteria pengambilan keputusan, subkriteria yang ada, pemangku kepentingan dan kelompok dipengaruhi dan alternatif tindakan yang diambil juga harus dipahami sebelum keputusan diambil.

Menurut Turban (2004, p136), definisi awal sistem pendukung keputusan (SPK) menunjukkan bahwa SPK sebagai sebuah sistem yang dimaksudkan untuk mendukung para pengambil keputusan menajerial dalam situasi keputusan semiterstruktur. Komponen SPK menurut Turban (2004, p.144) terdiri dari beberapa subsistem, yaitu susbsistem manajemen data, subsistem manajemen model, subsistem antarmuka pengguna, dan subsistem manajemen berbasis pengetahuan (Gambar 1). Turban (2004, p.141) juga mengungkapkan kemampuan utama suatu SPK adalah mendukungan pengambil keputusan, terutama pada situasi semiterstruktur dan tak terstruktur dengan menyertakan penilaian manusia dan informasi terkomputerisasi.

Pemanfaatan SPK memberikan banyak keuntungan bagi pengguna baik sebagai individu maupun kelompok, organisasi, dan pengembangan ilmu pengambilan keputusan itu sendiri. Pemanfaatan sistem SPK dalam suatu organisasi akan meningkatkan efisiensi pribadi, mempercepat proses pengambilan keputusan, meningkatkan pengendalian organisasi, mendorong eksplorasi dan penemuan pada bagian dari pembuat keputusan, mempercepat pemecahan masalah, memfasilitasi komunikasi interpersonal, mempromosikan pembelajaran atau pelatihan, menghasilkan bukti baru untuk mendukung keputusan, menciptakan keunggulan kompetitif dalam persaingan, mengungkapkan pendekatan baru untuk berpikir tentang masalah ruang, dan tentunya dapat membantu mengotomatisasikan proses manajerial. SPK dapat dimanfaatkan oleh semua level manajerial, dari eksekutif puncak sampai manajer lini baik secara individu maupun kelompok. Pengimplementasian SPK akan memberikan dukungan untuk pengambilan keputusan baik secara independen dan atau sekuensial, mendukung semua fase proses pengambilan keputusan, serta dapat mendukung berbagai proses dan gaya pengambilan keputusan. Oleh sebab itu sistem SPK akan memberikan peningkatan terhadap keefektifan pengambilan keputusan (akurasi, ketepatan waktu, kualitas) ketimbang pada efisiensinya (biaya pengambilan keputusan).

\section{Analytic Hierarchy Process (AHP)}

Analytic Hierarchy Process (AHP) adalah teknik terstruktur untuk mengatur dan menganalisis keputusan yang kompleks. AHP dikembangkan berdasarkan teori matematika dan psikologi oleh Thomas L. Saaty pada tahun 1970 dan telah diteliti secara luas serta disempurnakan sejak saat itu. Analytic Hierarchy Process (AHP) didefinisikan oleh Saaty (2008) sebagai teori pengukuran melalui perbandingan berpasangan dan bergantung pada penilaian dari para ahli untuk mendapatkan skala prioritas. AHP adalah suatu model yang luwes yang memberikan kesempatan bagi perseorangan atau kelompok untuk membagi gagasan-gagasan dan mendefinisikan persoalan dengan cara membuat asumsi mereka masing-masing dan memperoleh pemecahan yang diinginkan darinya. Permadi (1992) mendeifinisikan AHP sebagai sebuah hirarki fungsional dengan masukan utamanya persepsi manusia. Dengan hirarki, suatu masalah kompleks dan tidak terstruktur dipecahkan ke dalam kelompokkelompoknya. Kemudian kelompok-kelompok tersebut diatur menjadi suatu bentuk hirarki.

Ada tiga prinsip dasar AHP (Saaty, 1991, p28): (1) menggambarkan dan menguraikan secara hirarkis yang kita sebut menyusun secara hirarkis, yaitu memecah-mecah persoalan menjadi unsurunsur yang terpisah-pisah; (2) pembedaan prioritas dan sintesis, yang kita sebut penetapan prioritas, yaitu menentukan peringkat elemen-elemen menurut relatif pentingnya; (3) konsistensi logis, yaitu menjamin bahwa semua elemen dikelompokkan secara logis dan diperingkatkan secara konsisten sesuai dengan suatu kriteria yang logis. 


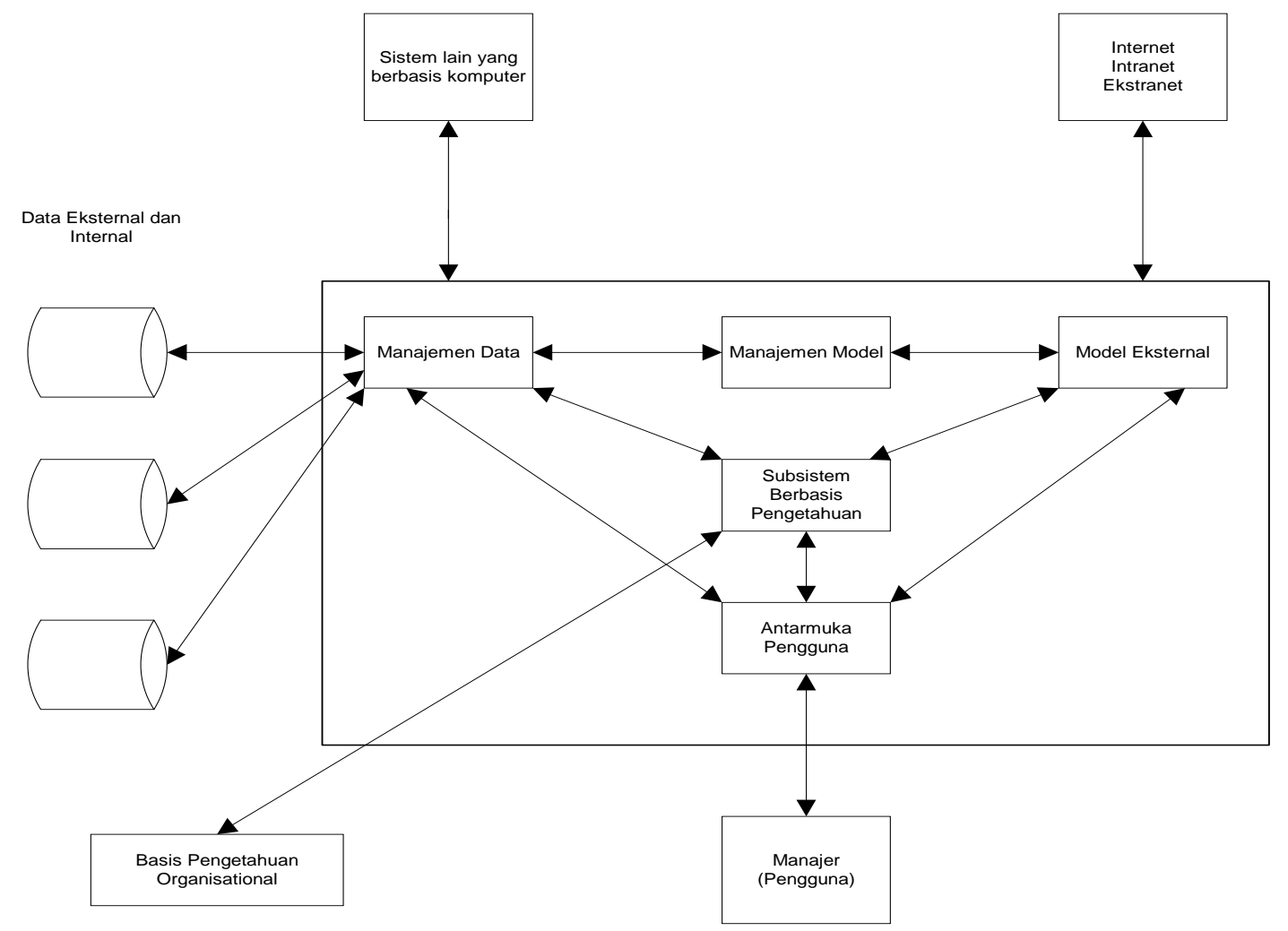

Gambar 1. Diagram sistem pendukung keputusan (Turban, 2004, p.144)

Selain itu, Saaty (1991, p25) juga menyebutkan berbagai keuntungan dari AHP yaitu: (1) kesatuan - AHP memberi satu model tunggal yang mudah dimengerti, luwes untuk aneka ragam persoalan tak terstruktur; (2) kompleksitas - AHP memadukan ancangan deduktif dan ancangan berdasarkan sistem dalam memecahkan persoalan kompleks; (3) saling ketergantungan - AHP dapat menangani saling ketergantungan elemen-elemen dalam suatu sistem dan tidak memaksakan pemikiran linier; (4) penyusunan hirarki - AHP mencerminkan kecenderungan alami pikiran untuk memilah-milah elemen suatu sistem dalam berbagai tingkat berlainan dan mengelompokkan struktur yang serupa dalam setiap tingkat; (5) pengukuran - AHP memberi suatu skala untuk mengukur hal-hal dan terwujud suatu metode untuk menetapkan prioritas; (6) konsistensi - AHP melacak konsistensi logis dari pertimbangan-pertimbangan yang digunakan dalam menetapkan berbagai prioritas; (7) sintetis - AHP menuntun ke suatu taksiran menyeluruh tentang kebaikan setiap alternative; (8) tawarmenawar - AHP mempertimbangkan prioritas-prioritas relatif dari berbagai faktor sistem dan memungkinkan orang memilih alternatif terbaik berdasarkan tujuan-tujuan mereka; (9) penilaian dan consensus - AHP tidak memaksakan konsensus tetapi mensintesis suatu hasil yang representatif dari berbagai penilaian yang berbeda-beda; (10) pengulangan proses - AHP memungkinkan orang memperhalus definisi mereka pada suatu persoalan dan memperbaiki pertimbangan dan pengertian mereka melalui pengulangan.

Sedangkan, Suryadi \& Ramdhani (2002, p.131) menyebutkan kelebihan AHP dibandingkan dengan yang lainnya, yaitu: (1) struktur berhierarki, sebagai konsekuensi dari kriteria yang dipilih, sampai pada subkriteria yang paling dalam; (2) memperhitungkan validitas sampai dengan batas toleransi inkonsistensi berbagai kriteria dan alternatif yang dipilih oleh para pengambil keputusan; (3) memperhitungkan daya tahan atau ketahanan keluaran analisis sensitivitas pengambilan keputusan. 
Langkah-langkah dalam metode AHP meliputi: (1) mendefinisikan masalah dan menentukan solusi yang diinginkan; (2) membuat struktur hierarki (Gambar 2) yang diawali dengan tujuan umum, dilanjutkan dengan kriteria dan kemungkinan alternatif-alternatif pada tingkatan kriteria paling bawah; (3) membuat matriks-matriks perbandingan berpasangan dan menggambarkan kontribusi relatif atau pengaruh setiap elemen terhadap masing-masing tujuan atau kriteria yang setingkat diatasnya. Perbandingan dilakukan berdasarkan judgement dari pengambil keputusan dengan menilai tingkat kepentingan suatu elemen dibandingkan elemen lainnya.

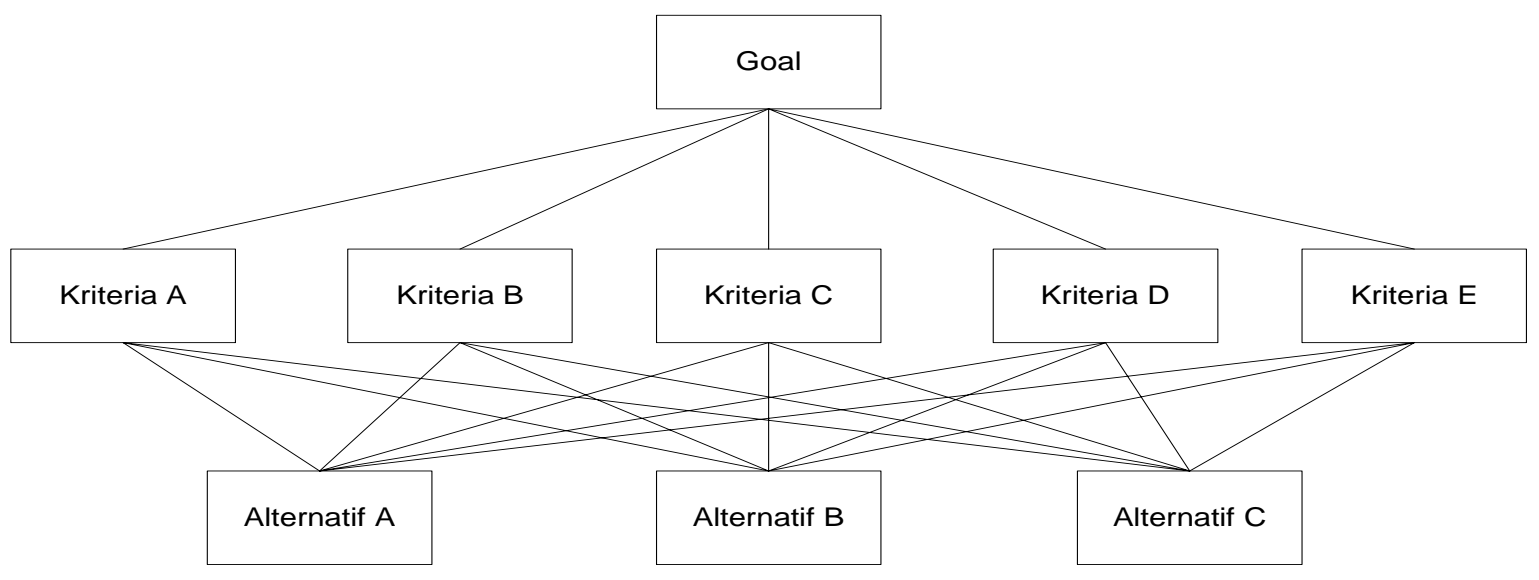

Gambar 2. Struktur Hierarki AHP (Suryadi dan Ramdhani, 2002, p.140)

Saaty menetapkan skala kuantitatif 1 sampai dengan 9 untuk menilai perbandingan tingkat kepentingan suatu elemen terhadap elemen lainnya (Tabel 1).

Tabel 1

Skala Penilaian Perbandingan Berpasangan (Suryadi dan Ramdhani, 2002, p.132)

\begin{tabular}{cll}
$\begin{array}{c}\text { Intensitas dari } \\
\text { kepentingan pada } \\
\text { skala absolut }\end{array}$ & \multicolumn{1}{c}{ Definisi } & \multicolumn{1}{c}{ Penjelasan } \\
\hline 1 & Kedua Elemen Sama Pentingnya. & $\begin{array}{l}\text { Dua elemen mempunyai pengaruh yang } \\
\text { sama }\end{array}$ \\
\hline 3 & $\begin{array}{l}\text { Elemen yang satu sedikit lebih penting dari } \\
\text { elemen lainnya }\end{array}$ & $\begin{array}{l}\text { Pengalaman dan penilaian sedikit } \\
\text { menyokong 1 elemen dibanding elemen } \\
\text { lain }\end{array}$ \\
\hline 5 & $\begin{array}{l}\text { Elemen yang satu lebih penting dari elemen } \\
\text { lainnya }\end{array}$ & $\begin{array}{l}\text { Pengalaman dan penilaian sangat kuat } \\
\text { menyokong 1 elemen dibanding elemen } \\
\text { lain }\end{array}$ \\
\hline 7 & $\begin{array}{l}\text { Satu elemen jelas lebih mutlak penting dari } \\
\text { elemen lainnya }\end{array}$ & $\begin{array}{l}\text { Satu elemen yang kuat disokong dan } \\
\text { dominant terlihat dalam praktek }\end{array}$ \\
\hline $2,4,6,8$ & $\begin{array}{l}\text { Satu elemen mutlak penting daripada elemen } \\
\text { lainnya }\end{array}$ & $\begin{array}{l}\text { Bukti menyukai satu aktivitas atas } \\
\text { yang lain sangat kuat }\end{array}$ \\
\hline Kebalikangilai antara dua nilai pertimbangan & $\begin{array}{l}\text { Nilai ini diberikan bila ada kompromi } \\
\text { diantara dua pilihan }\end{array}$ \\
\hline & $\begin{array}{l}\text { Jika untuk aktivitas i mendapat 1 angka dibanding dengan aktifitas } j, j \text { mempunyai nilai } \\
\text { kebalikannya dibanding dengan } i\end{array}$ & \\
\hline
\end{tabular}




\section{Analisis Sistem Berjalan}

Berikut adalah tata laksana sistem procurement yang sedang berjalan: (1) Bagian Penjualan (Sales) membuat Surat Permintaan Pembelian Barang (SPPB) dan memberikannya kepada Bagian Purchasing dan Bagian Logistik; (2) setelah SPPB diterima, Bagian Purchasing lalu membuat dan mengirimkan Surat Permintaan Penawaran Harga (SPPH) kepada pemasok. Selanjutnya pemasok akan mengirimkan Surat Penawaran Harga (SPH) kepada Bagian Purchasing; (3) setelah Surat Penawaran Harga diterima dari pemasok, pihak manajemen dan Bagian Purchasing melakukan analisis untuk pemilihan pemasok yang paling sesuai. Setelah pemasok dipilih, selanjutnya Bagian Purchasing akan membuat dan mengirimkan Surat Pembelian Barang (SPB) kepada pemasok. Salinan dari Surat Pembelian Barang lalu diserahkan kepada Bagian Finance; (4) pemasok mengirimkan Order Ackowledgement kepada Bagian Purchasing sebagai konfirmasi atas Surat Pembelian Barang yang telah dikirimkan. Salinan dari Order Acknowledgement lalu diserahkan kepada Bagian Finance; (5) Bagian Purchasing melakukan Purchase Tracking; (6) pemasok mengirimkan barang yang dipesan beserta surat jalan dan packing list kepada bagian pembelian; (7) Bagian Purchasing melakukan Quality Control terhadap barang yang dikirim oleh pemasok, lalu dilakukan labeling "Pass/Reject"; (8) apabila ada barang yang "reject", Bagian Purchasing akan melakukan retur ke pemasok; (9) pemasok mengirimkan surat jalan dan packing list beserta invoice kepada Bagian Finance; (10) Bagian Finance memasukkan invoice dari pemasok ke dalam Aging Account Payable; (11) Bagian Purchasing mentransfer barang ke bagian logistik. Surat Jalan dan Packing List diserahkan ke Bagian Logistik; (12) barang disimpan oleh Bagian Logistik dan dilakukan inventory record oleh Bagian Logistik. Untuk lebih jelasnya, lihat Gambar 3 dan 4.

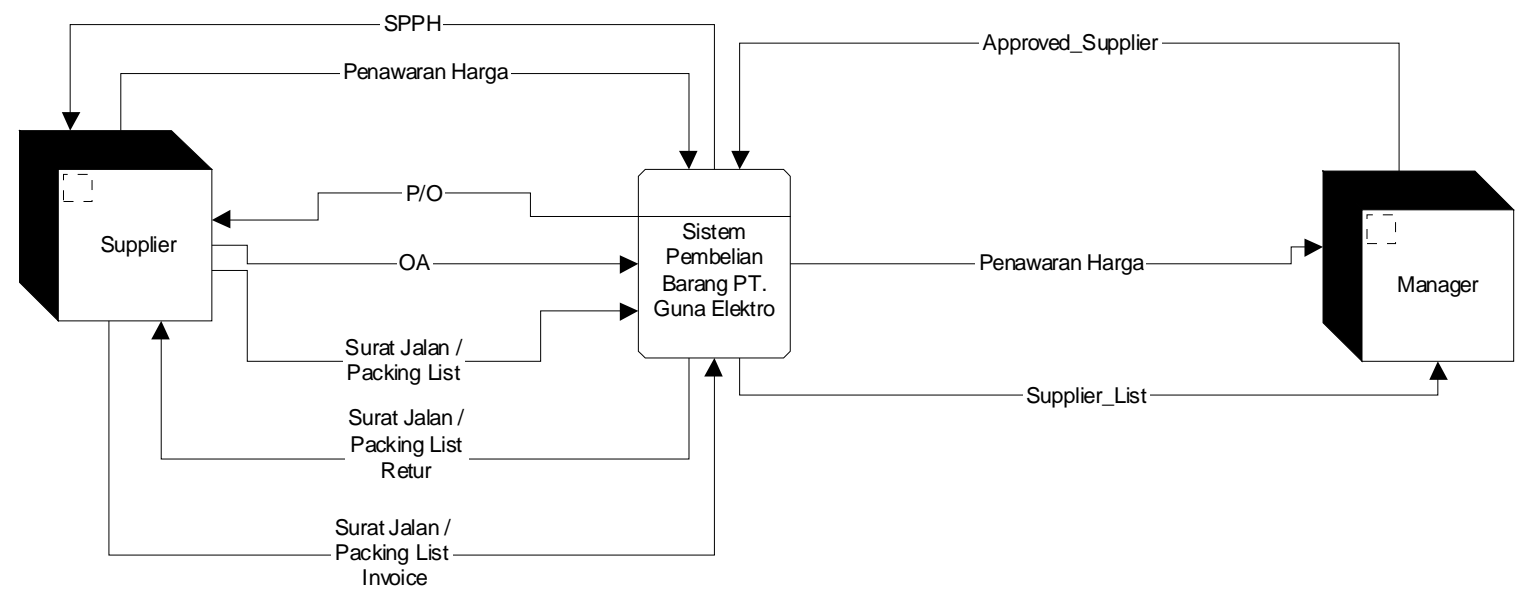

Gambar 3. Diagram Konteks Sistem Procurement.

Adapun kelemahan proses yang berjalan, yaitu pemilihan pemasok dari Daftar Pemasok biasanya dilakukan hanya berdasarkan pengalaman dan penilaian subyektif, sehingga dapat terjadi kesalahan di mana pemasok yang dipilih tidak sesuai dengan kriteria yang diinginkan. Selain itu, belum ada suatu sistem yang dapat membantu atau mendukung proses pemilihan pemasok dari Daftar Pemasok.

Untuk mengatasi kelemahan proses ini, diusulkan untuk: (1) membuat suatu sistem untuk mendukung dan membantu proses pemilihan pemasok; (2) menggunakan metode AHP untuk pemilihan pemasok, sehingga pemilihan pemasok menjadi lebih obyektif; (3) menggunakan metode AHP yang akan memberikan ranking pemasok sesuai dengan kriteria yang diinginkan. 


\section{Usulan Sistem Pendukung Keputusan}

Rancangan sistem yang diusulkan untuk digunakan oleh Divisi Power PT Guna Elektro adalah sebuah sistem pendukung keputusan yang berfungsi untuk membantu manajer dalam mengambil keputusan dalam menentukan pemasok yang paling sesuai.

Sistem pendukung keputusan ini menggunakan metode Analytic Hierarchy Process (AHP) yang pada intinya melakukan perhitungan bobot dari kriteria-kriteria yang pada akhirnya akan menghasilkan alternatif-alternatif terbaik untuk membantu proses pengambilan keputusan. Adapun sistem yang akan dirancang terdiri dari komponen-komponen yang digambarkan oleh Gambar 5.

Komponen sistem yang akan dikembangkan dapat dijelaskan sebagai berikut. Subsistem Manajemen Data (Gambar 6) berisi data internal maupun eksternal yang relevan dan dibutuhkan oleh sistem. Data tersebut dikelola oleh sistem manajemen basis data (DBMS). Subsistem Manajemen Model merupakan manajemen model yang digunakan oleh sistem. Dalam hal ini model eksternal yang digunakan adalah Analytic Hierarchy Process atau AHP. Sedangkan aubsistem Antarmuka Pengguna merupakan komponen yang digunakan oleh user untuk berinteraksi dengan sistem. Dalam hal ini bahasa pemrograman yang digunakan adalah Visual Basic.NET.

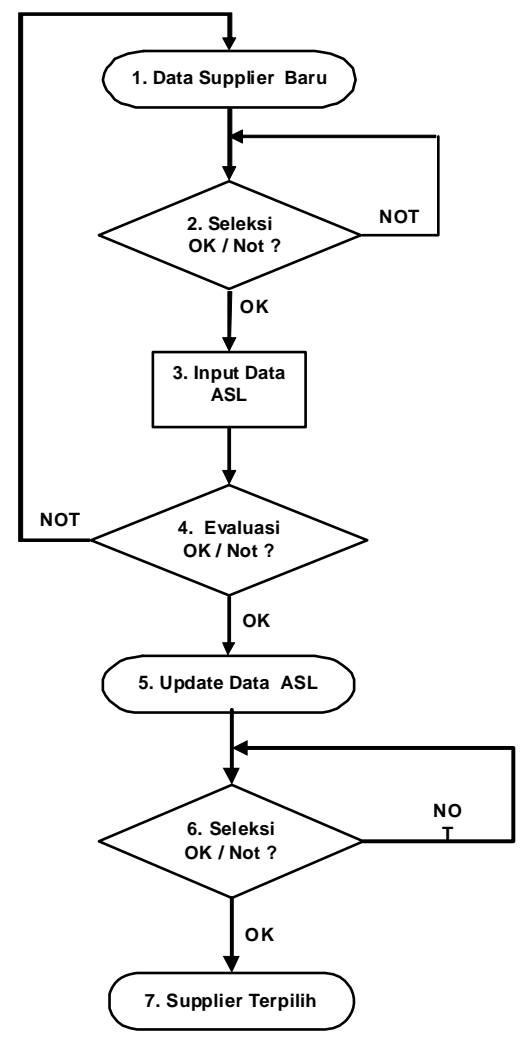

Gambar 4. Alur detail proses seleksi pemasok.

\section{Rancangan Subsistem Manajemen Model}

Sistem Pendukung Keputusan ini menggunakan model Analytic Hierarchy Process (AHP). Model AHP digunakan untuk membantu manajer mengambil keputusan untuk memilih pemasok terbaik (Gambar 7). Ada tujuh kriteria yang digunakan dalam pemilihan pemasok, yaitu: delivery lead time, on time delivery, quantity, quality, reputation, technical support, dan price. 


\section{Rancangan Subsistem Manajemen Data}

Berikut adalah rancangannya (Gambar 6). Kriteria-kriteria di di bawah ini akan digunakan dalam pemodelan dengan menggunakan AHP (Tabel 2).

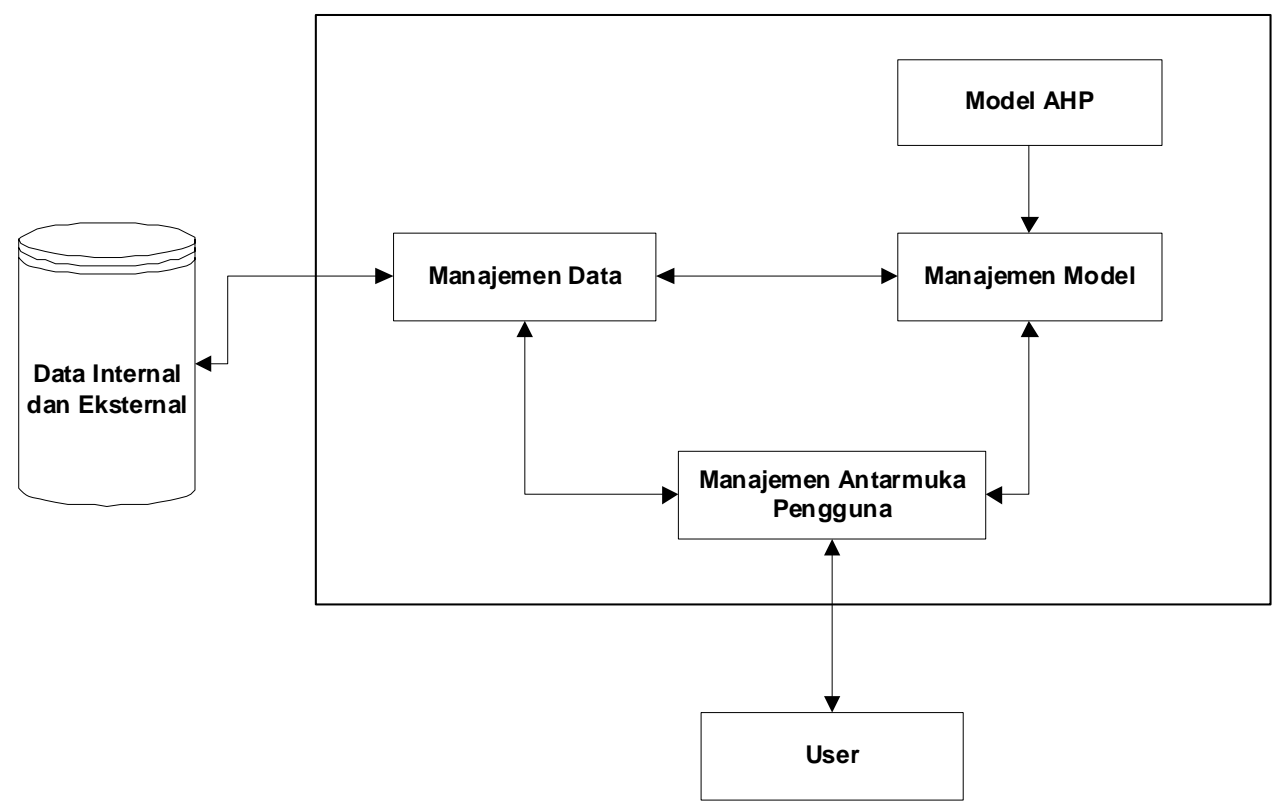

Gambar 5. Rancangan sistem.

Data-data kriteria tersebut dengan pengecualian Price akan diperoleh dari nilai evaluasi pemasok yang dilakukan PT Guna Elektro sebanyak dua kali dalam setahun. Untuk Price, data baru dapat diperoleh setelah mendapat Quotation atau surat penawaran harga dari pemasok.

Data nilai evaluasi pemasok yang dilakukan perusahaan berskala 1 sampai dengan 5 . Nilai tersebut akan dikonversi ke dalam skala preferensi AHP dengan menggunakan Rumus:

$$
\mathrm{N}=\mathrm{S} \times 2
$$

di mana $S$ adalah selisih nilai evaluasi dua pemasok yang diperbandingkan untuk tiap kriteria. Contohnya, untuk kriteria quality, pemasok A mempunyai nilai 5 dan pemasok B mempunyai nilai 3, maka:

$\mathrm{N}=(5-3) \times 2$

$\mathrm{N}=4$

Dengan demikian, skala perbandingan pemasok A terhadap B adalah 4. 


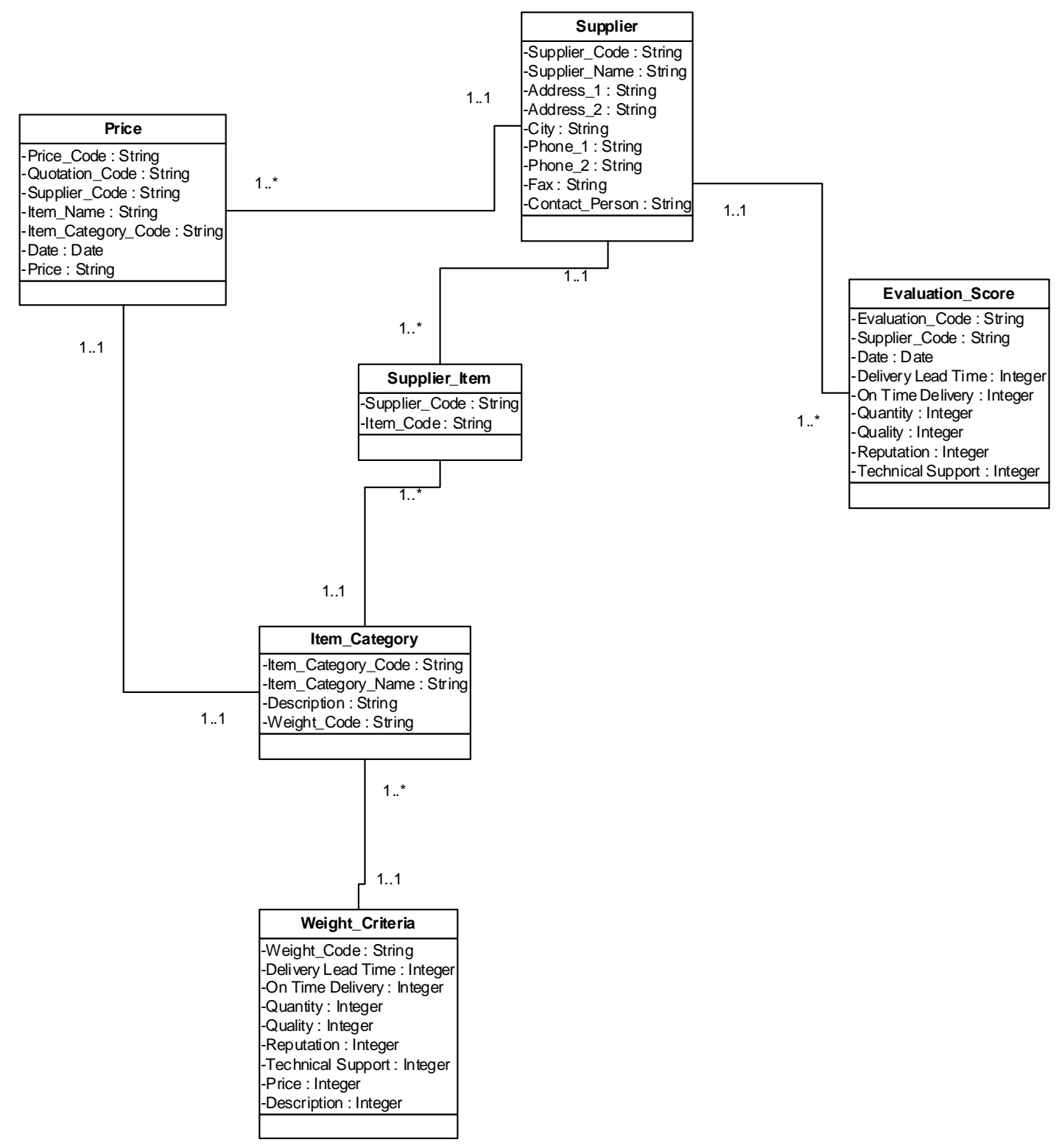

Gambar 6. Rancangan Entity Relationship Diagram.

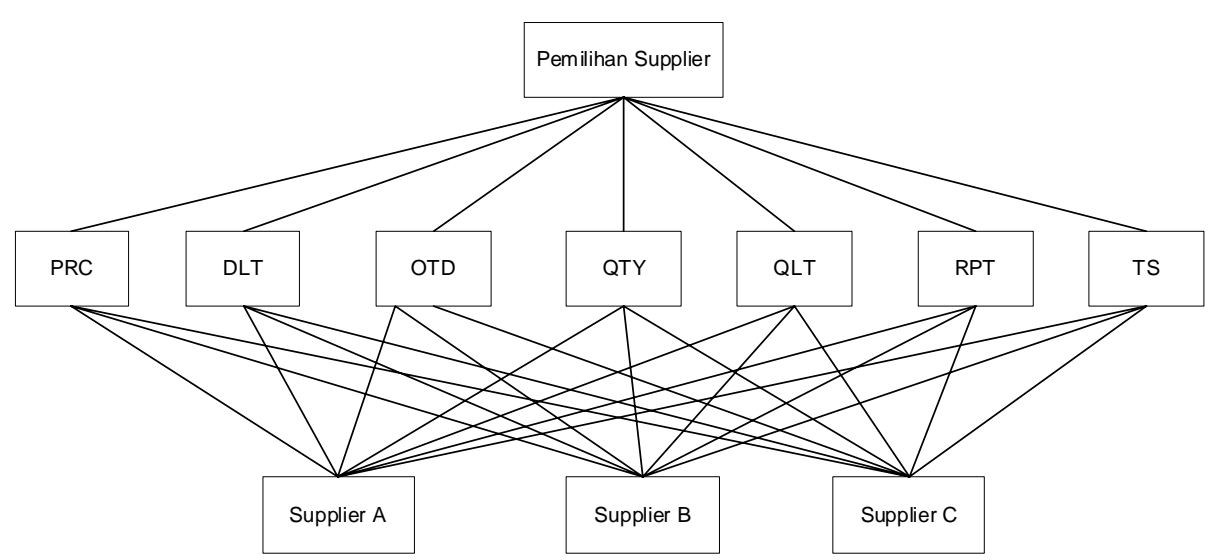

Gambar 7. Hierarki keputusan pemilihan pemasok. 
Tabel 2

Kriteria Pemilihan Pemasok

\begin{tabular}{lll}
\hline \multicolumn{1}{c}{ Kode Kriteria } & \multicolumn{1}{c}{ Nama Kriteria } & \multicolumn{1}{c}{ Keterangan } \\
\hline$P R C$ & Price & Harga penawaran yang ditawarkan oleh pemasok \\
$D L T$ & Delivery Lead Time & $\begin{array}{l}\text { Lamanya waktu dari PO dikeluarkan sampai barang } \\
\text { tersebut sampai di gudang }\end{array}$ \\
\hline OTD & On Time Delivery & Ketepatan waktu pengiriman \\
\hline$Q T Y$ & Quantiy & Kesesuaian jumlah barang saat dikirim \\
\hline QLT & Quality & Kualitas barang, jumlah barang cacat/reject \\
\hline$T C P$ & Reputation & Reputasi pemasok yang bersangkutan \\
\hline
\end{tabular}

\section{Rancangan Subsistem Antarmuka Pengguna}

Berikut adalah rancangannya (Gambar 8).

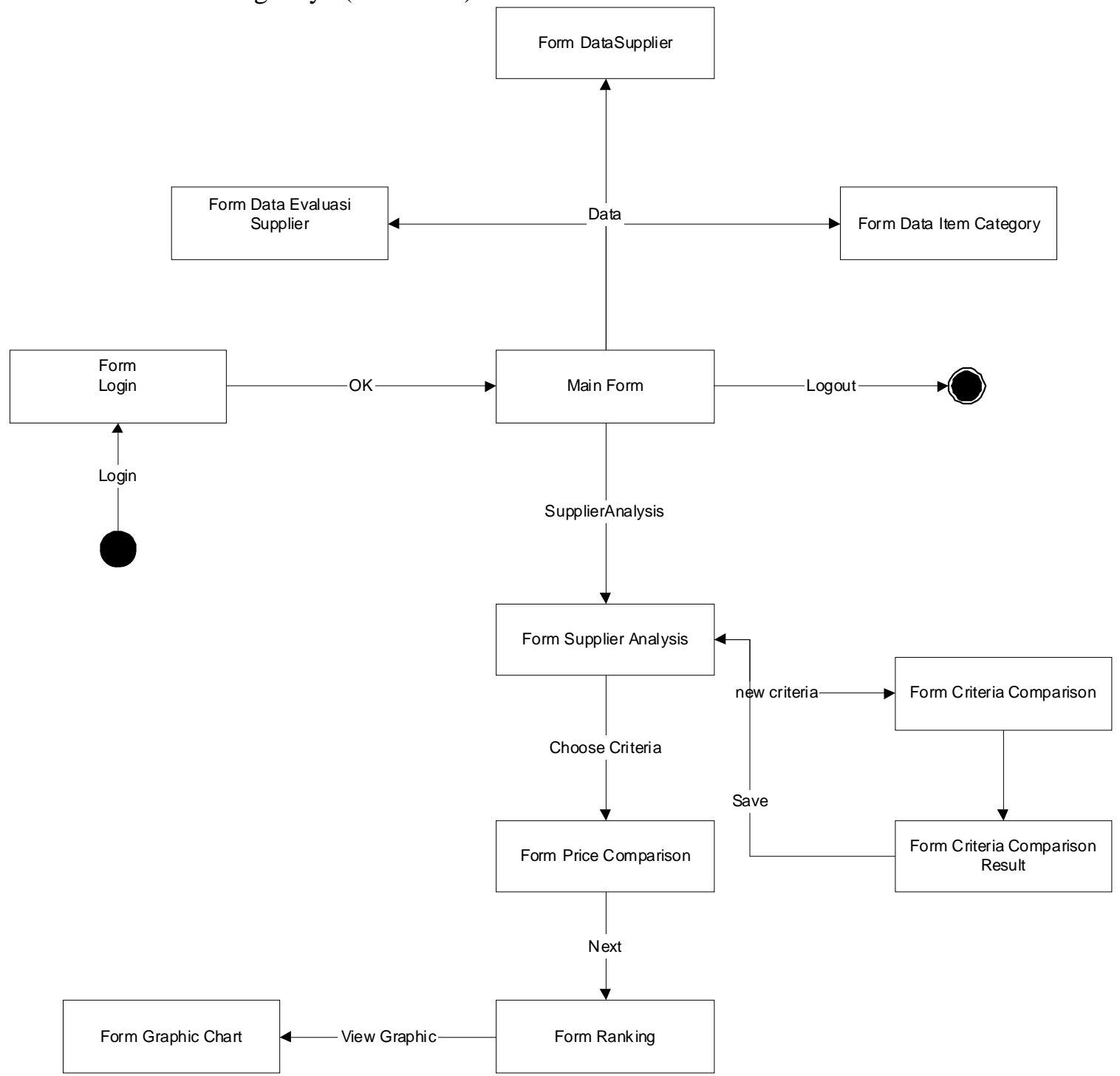

Gambar 8. State transition diagram. 
Pada sistem SPK yang dikembangkan, masukan untuk perhitungan AHP dikategorikan menjadi tiga, yaitu: input perbandingan antar kriteria, input perbandingan price antar pemasok (supplier), dan input perbandingan kriteria lainnya antar pemasok (supplier).

\section{Rancangan Dialog}

Tampilan jendela awal yang muncul saat pertama kali program dijalankan adalah jendela login. Setelah pengguna memasukkan username dan password dan terverifikasi oleh sistem, akan muncul Main Form dengan pilihan menu File, Menu, Data, dan Help. Pilihan Data untuk melihat master data sedangkan pada pilihan Menu terdapat sub menu Analysis untuk membuka Form Analysis (Gambar 9). Dalam form ini, pertama dapat dipilih kategori item, kemudian dipilih dari list, minimal harus dipilih dua pemasok (supplier) untuk dibandingkan. Setelah itu pengguna harus menentukan bobot kriteria pada list criteria (Gambar 10), atau dipilih New Criteria untuk membuat perbandingan baru. Pilihan Choose Criteria akan membuka Form Price Comparison. Form ini berfungi untuk membandingkan antar criteria. Criteria dapat dipilih dalam combo box lalu set slider digunakan untuk membandingkan setiap criteria yang kemudian dapat disimpan.

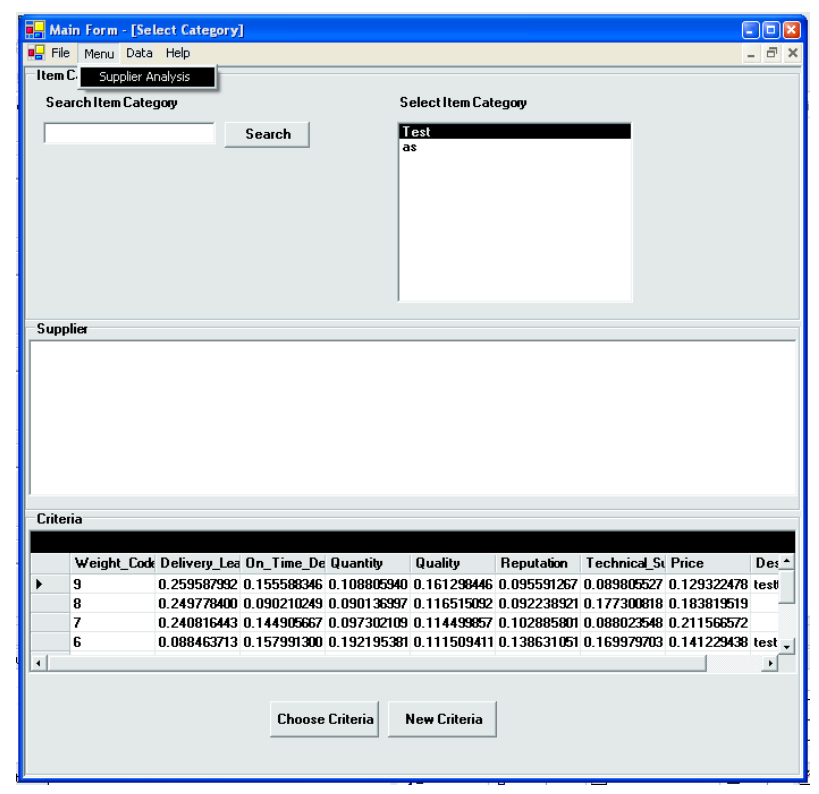

Gambar 9. Formulir Supplier Analysis.

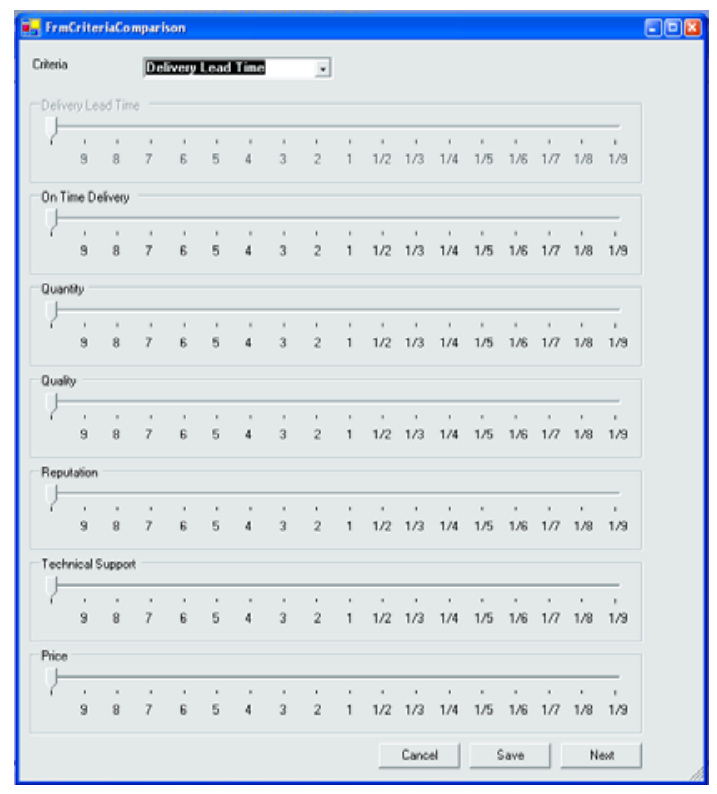

Gambar 10. Criteria Comparison.

Formulir Comparison Result (Gambar 11) menampilkan hasil dari perbandingan kriteria yang dilakukan sebelumnya. Pengguna bisa menambahkan deskripsi berupa nama atau keterangan dan setelah itu dapat disimpan. Proses selanjutnya akan kembali pada Formulir Supplier Analysis. Form Price Comparison (Gambar 12) digunakan untuk melakukan perbandingan harga antar pemasok (supplier). Angka pembanding untuk tiap supplier-nya harus ditentukan lalu pilih "Next".

Setelah semua dibandingkan maka akan ditampilkan Form ranking (Gambar 13). Form Ranking yang akan menampilkan ranking pemasok (supplier) berdasarkan perhitungan AHP yang telah dilakukan. Jika ingin melihat per kriteria saja maka beri tanda pada checked list box criteria di bagian tengah form dan dapat ditampilkan chart per pemasok (supplier) dengan memilih View Graphic (Gambar 14). 

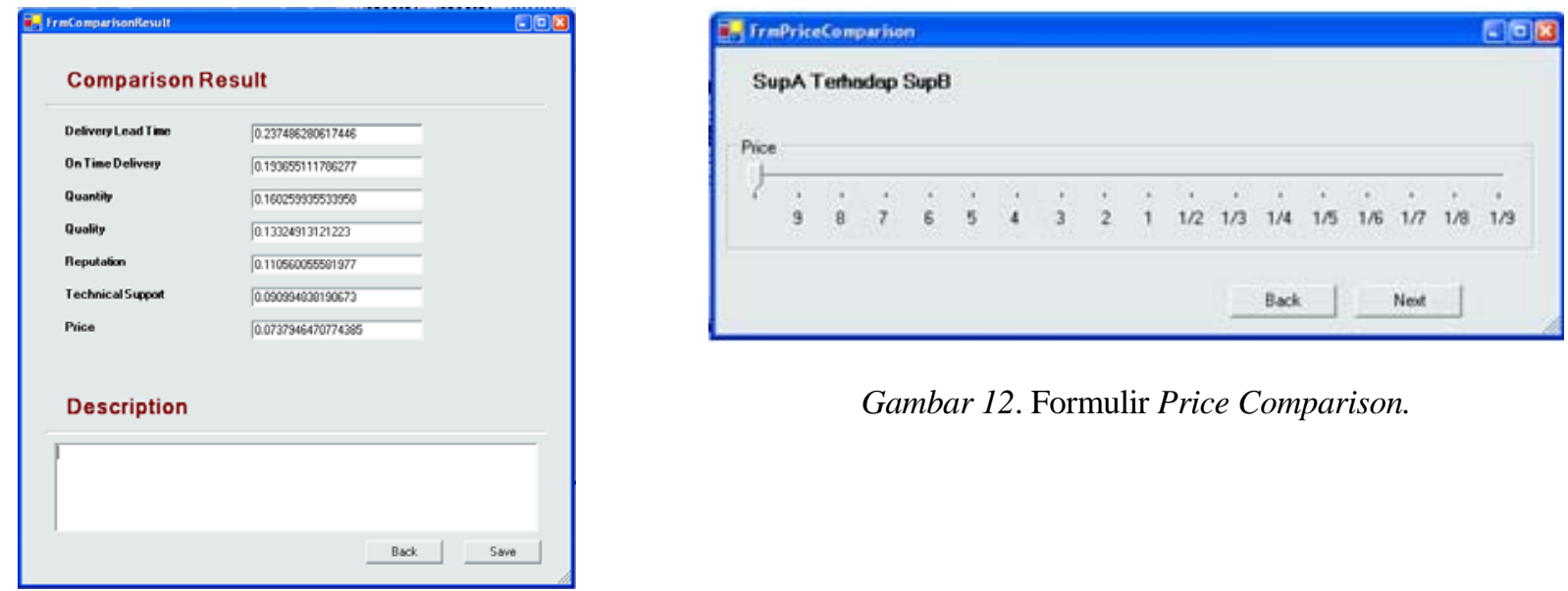

Gambar 12. Formulir Price Comparison.

Gambar 11. Formulir Comparison Result.

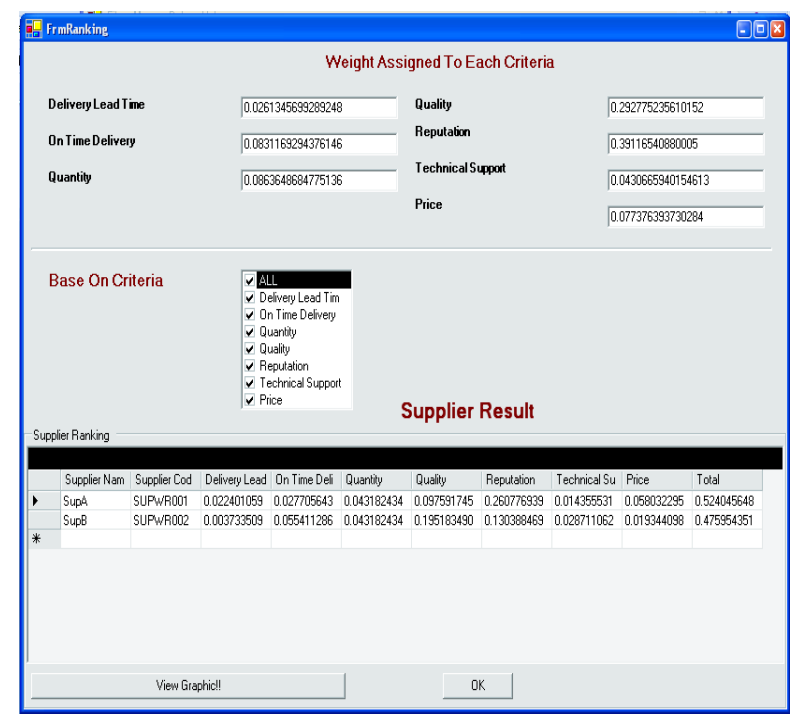

Gambar 13. Formulir Ranking.

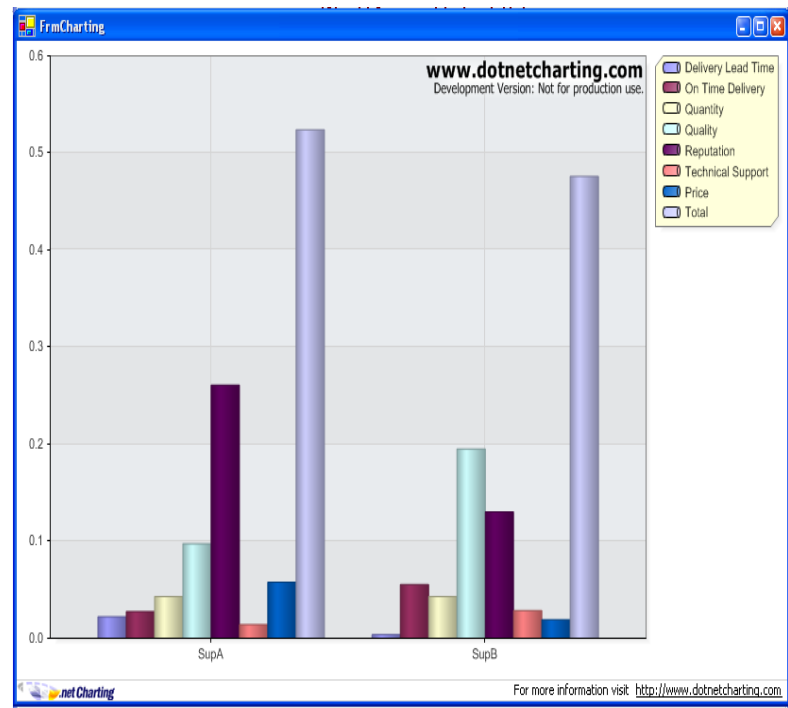

Gambar 14. Tampilan grafik.

Formulir Data Item Category (Gambar 15) dapat diakses melalui pilihan menu Data dan digunakan untuk menampilkan list item category. Dari formulir ini dapat dilakukan input data baru, mengedit data yang ada, serta menyimpannya atau membatalkannya. Sedangkan, Formulir Data Supplier (Gambar 16) untuk menampilkan daftar pemasok (list supplier). Di sini juga dapat dilakukan input data baru, mengedit data yang ada, serta menyimpannya atau membatalkannya. Berikutnya adalah Formulir Data Evaluasi Supplier untuk menampilkan daftar nilai evaluasi supplier. Dalam form ini juga dapat dilakukan input data baru, pengubahan data yang ada, dan penyimpanan data.

Hasil akhir analisis ini akan ditampilkan pada Form Hasil Akhir (Gambar 17). Pilihan-pilihan yang sudah ada dan telah dipilih oleh manajer akan ditampilkan nama, alamat serta bobot setiap kriteria dari pemasok terpilih dirinci lebih spesifik. 


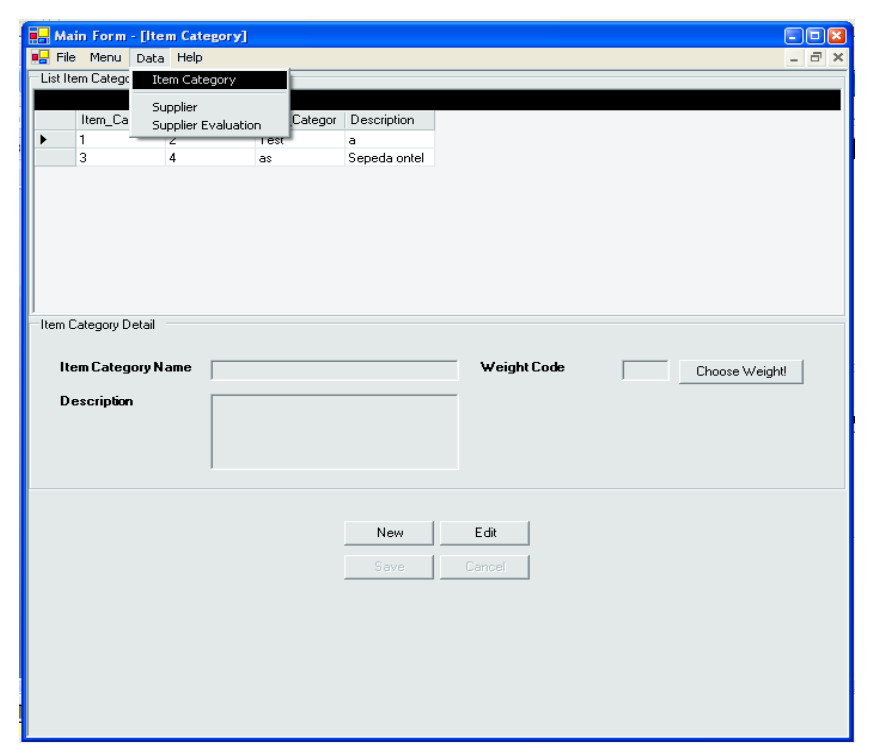

Gambar 15. Formulir Data Item Category.

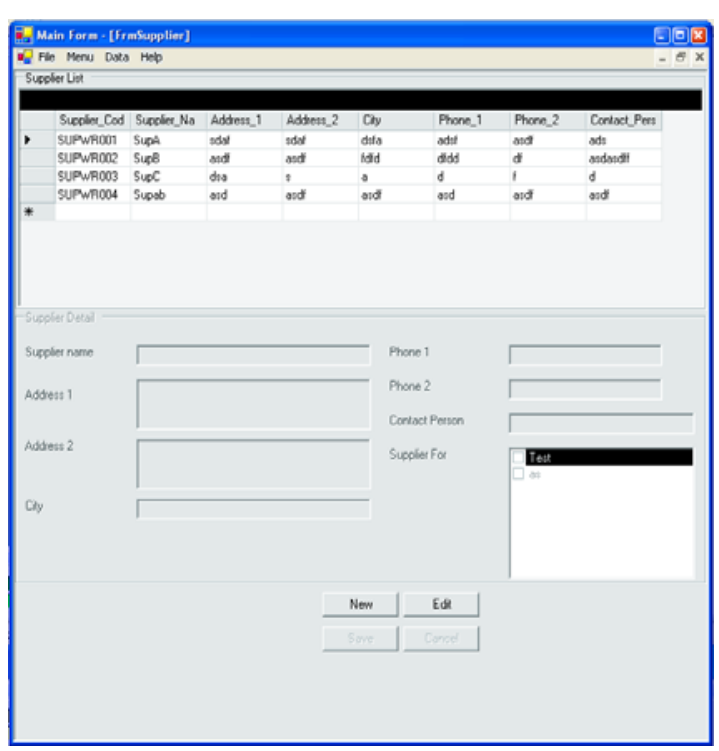

Gambar 16. Formulir Data Supplier.
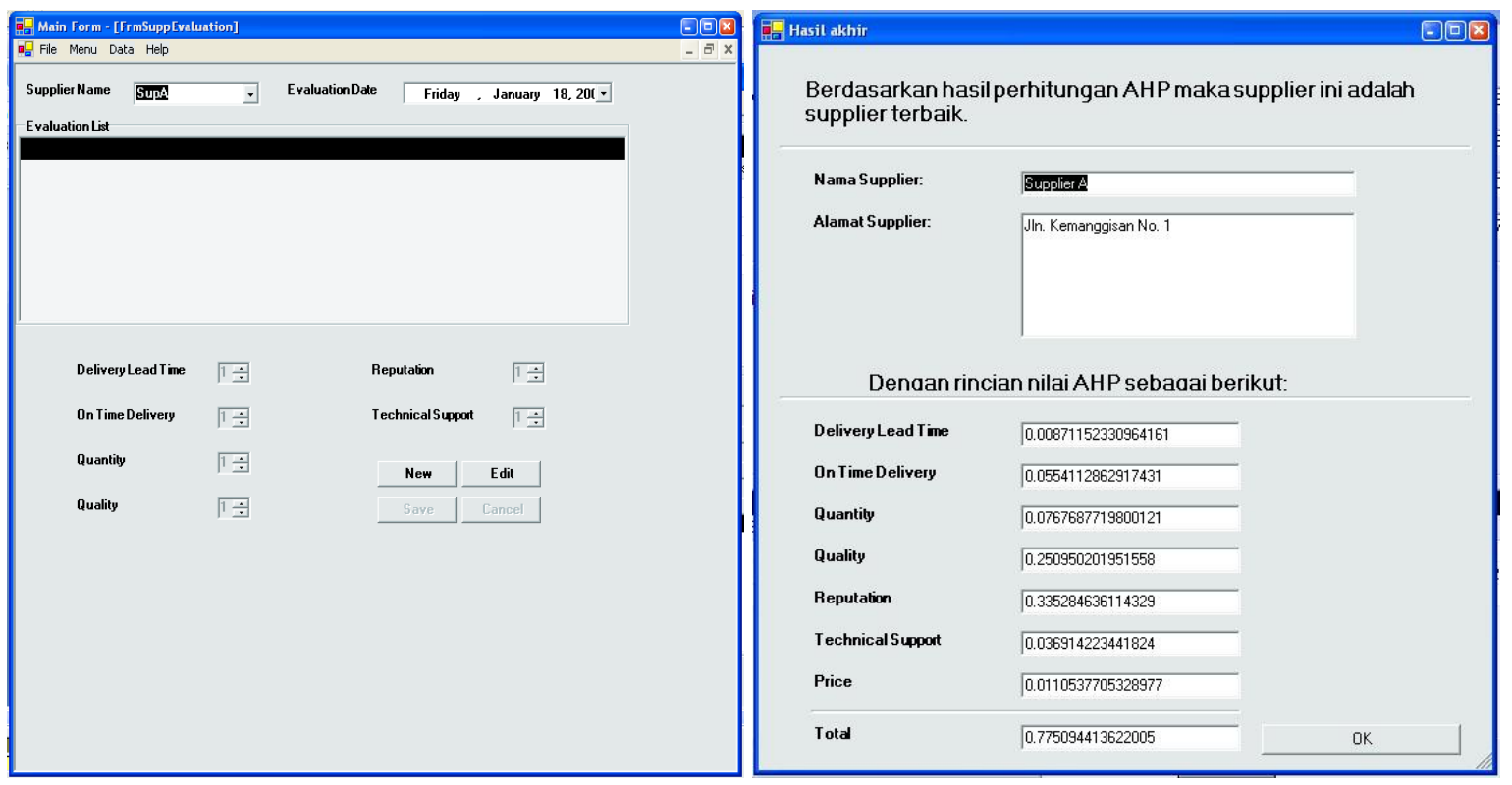

Gambar 17. Formulir Data Evaluasi Supplier.

\section{PENUTUP}

Dari hasil Analisis dan Perancangan Sistem Pendukung Keputusan Pemilihan Pemasok Terbaik dari Pemasok yang Tersedia dengan Metode Analytical Hierarchy Process (AHP) Studi Kasus Divisi Power PT Guna Elektro, telah berhasil dikembangan suatu SPK Pemilihan Pemasok yang membantu mendukung proses pengambilan keputusan untuk pemilihan pemasok terbaik dari Daftar Pemasok. Dengan memanfaatkan sistem ini proses pemilihan pemasok terbaik dari Daftar Pemasok menjadi lebih mudah dan lebih objektif selain itu keluaran sistem ini menghasilkan ranking pemasok yang tepat sesuai dengan kriteria yang ditetapkan. Ini dapat tercapai karena SPK Pemilihan Pemasok 
yang dikembangkan menggunakan perhitungan AHP berdasarkan harga penawaran, nilai evaluasi, dan kriteria yang ditetapkan. Dari sisi pengoperasian aplikasi ini oleh pengguna, sistem ini tidak memerlukan pelatihan khusus bagi pemakai karena dirancang sedemikian sehingga mudah untuk digunakan. Hanya dengan melihat tampilan-tampilan yang telah dirancang, pengguna dapat langsung menggunakan aplikasi ini.

Beberapa saran yang dapat diberikan pada studi ini, yaitu SPK Pemilihan Pemasok yang telah dikembangkan ini sebaiknya terus dievaluasi dan dikembangkan sesuai dengan situasi dan kondisi yang dihadapi oleh perusahaan. Selain itu SPK Pemilihan Pemasok ini sebenarnya dapat diperluas pengunaannya pada divisi-divisi lain pada perusahaan.

\section{DAFTAR PUSTAKA}

Saaty, T. L. (1991). Pengambilan Keputusan Seri Manajemen No. 134. Jakarta: Binaman Pressindo.

Saaty, T. L. (2008). Decision Making with the Analytic Hierarchy Process. Int. J. Services Sciences, 1(1): 83-98.

Suryadi, Kadarsah dan Ramadani, M. Ali. (2002). Sistem Pendukung Keputusan: Suatu Wacana Struktural Idealisasi dan Implementasi. Bandung: Remaja Rosdakarya.

Turban, Efraim, dan Aronson, Jay E. (2004). Decision Support Systems and Intelligent Systems (11 ${ }^{\text {st }}$ ed.). Yogyakarta: Penerbit ANDI. 